\title{
Heat Transfer Analysis of Solar Fish Drying Machine on the Effects of Fish Mass and Blower Speed Variations
}

\author{
Mokhammad Fahmi Izdiharrudin ${ }^{1}$, Ridho Hantoro ${ }^{1}$, Selvy Uftovia Hepriyadi ${ }^{1,2}$ \\ ${ }^{1}$ Department of Engineering Physics, Faculty of Industrial Technology, Institut Teknologi Sepuluh Nopember, Surabaya, Indonesia \\ ${ }^{2}$ Graduate Institute of Electro-Optical Engineering, National Taiwan University of Science and Technolgy, Taipei, Taiwan
}

\section{Email address:}

mokh.fahmizdi@gmail.com (M. F. Izdiharrudin)

\section{To cite this article:}

Mokhammad Fahmi Izdiharrudin, Ridho Hantoro, Selvy Uftovia Hepriyadi. Heat Transfer Analysis of Solar Fish Drying Machine on the Effects of Fish Mass and Blower Speed Variations. American Journal of Modern Energy. Vol. 5, No. 2, 2019, pp. 19-22.

doi: $10.11648 /$ j.ajme.20190502.13

Received: March 18, 2019; Accepted: April 25, 2019; Published: June 4, 2019

\begin{abstract}
Traditional fish drying process still has not met the norm of food safety and health terms in accordance with Good Manufacturing Practice (GMP). Therefore, it is necessary to design the technology of fish drying process efficiently for healthier food. This study carried out with the experimental and the simulation methods. The experimental study shows that the final moisture content of the fish is below $10 \%$ for 6 hours drying (from 9 a.m. to 2 p.m.) using solar fish drying machine. The simulation using Computational Fluid Dynamics (CFD) conducted to gain deeper information of heat transfer phenomena. Steady state condition that utilizes momentum calculation, energy, continuity, and the radiation equation of S2S (Surface to Surface) modeled with the variation of mass of $2 \mathrm{~kg}$ and $5 \mathrm{~kg}$. It found that 6 hours of irradiation for $5 \mathrm{~kg}$ of fish was not able to reach $10 \%$ moisture content. However, the $2 \mathrm{~kg}$ fish can achieve the expected moisture content with the efficiency of drying reaches $19 \%$ with a blower speed of 1500 RPM. The variations of $1500-1850$ RPM blower show linear correlation to the efficiency of the solar drying machine. While, the highest efficiency was reached $23 \%$ and occurred at 1850 RPM of blower speed.
\end{abstract}

Keywords: Blower Speed, Computational Fluid Dynamics (CFD), Fish Drying, Heat Transfer

\section{Introduction}

Nambangan is a fishery area that has fish yields up to approximately 1 ton per day during the fish finding from $8 \mathrm{pm}$ to $4 \mathrm{am}$. The work area for the fisherman is the ocean around the Madura Strait and its surroundings. The yields are then sold to fish collectors in the bulak fish center in fresh condition. They are selling fishes in fresh and half-cooked conditions. Half-cooked fishes are usually processed through drying and fumigation using a conventional method. Nowadays, as the development of food drying technology, it is necessary to implement our proposed technology.

The previous drying technology has done by Ekadewi [1], which was able to produce a decrease in moisture content up to $58.3 \%$ with the irradiation condition of $500 \mathrm{~W} / \mathrm{m}^{2}$ and the drying time of 6 hours. Furthermore, research conducted by Sukarmanto [2] was able to produce a reduction in moisture content up to $64 \%$ with the irradiation conditions ranging from $400 \mathrm{~W} / \mathrm{m}^{2}$ and the drying time for 3 days. Therefore, the author conducted the research to optimize the fish drying process with the type of indirect system drying.

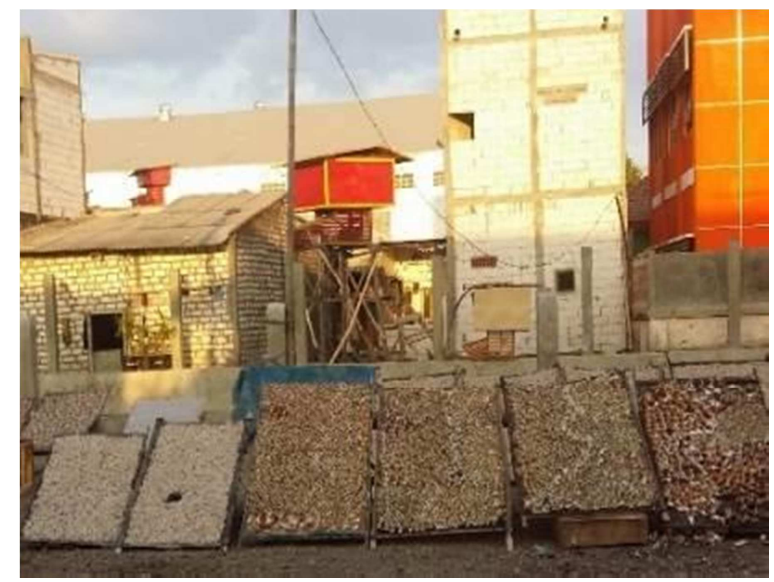

Figure 1. Traditional fish drying process in Nambangan. 
The forced ventilation and solar collector are used. Because, based on the research conducted by Kumar [3], it obtained that this type has the best efficiency than the other types. The drying process using the solar collector assisted with $30 \mathrm{~W}$ blower. This solar drying machine is also equipped with photovoltaic as an energy source for the blower. This experimental study has been published [4] and shows that the solar collector reduced the drying time up to 4-6 hours faster than traditional drying methods with an average solar irradiation condition of $1.8-844.6 \mathrm{~W} / \mathrm{m}^{2}$. It also reduced the moisture content up to below $10 \%$. Therefore, the drying machine can be used three times a day. The final moisture content of the dried fish is $3.12 \%$ for $3 \mathrm{~kg}$ of bulu ayam fish, $2.07 \%$ for $2 \mathrm{~kg}$ of bulu ayam fish, and $1.12 \%$ for $2 \mathrm{~kg}$ of bulu menthog fish.

To optimize the result of the experimental study of the drying machine, it is necessary to conduct simulation-based study on the effects of fish mass and blower speed variations. In addition, the research is potential to save the costs and time due to the increase of its efficiency. The simulation process consist of the design that using CAD software, meshing, determining parameters, and calculation. From the simulation, it obtained the temperature contours at each point of the tools. Therefore, the analysis of the energy can be carried out to optimize the results of the drying process. By doing the simulation, it is expected that the level of fish drying production can increase.

\section{Drying Process}

Drying is the process of removing volatile substances (moisture content) from solids [11]. The process carried out by increasing the partial pressure of water vapor of the fish by giving heat and increasing the relative humidity of the drying air. The ability of the air to carry the moisture out as the difference of the partial pressure of water vapor in the air is greater. Drying is a complex process of mass and heat transfer that depends on the external parameters such as temperature, air humidity, velocity of the air, characteristics of the fish surface, and the chemical composition of the dried material [10]. In the drying process, there is a mass transfer of water vapor from the dried material to the drying air. The process divided into two stages that are the mass transfer of water vapor from the inside to the surface of the dried material and the mass transfer of water vapor from the surface of the dried material to the drying air. The movement of the water vapor from the inside to the surface of the material occurs because of the difference of concentration. The concentration of the water inside the material is greater than the concentration of the water on the surface of the material. Assuming a thin layer, the movement of water vapor from the material to the surface can be determined by the Fick equation for one-dimensional diffusion [7]. The moisture transfer from the surface of the material to the drying air takes place by the convection process A certain amount of the steam is needed. So, the mass of the water inside the fish can be evaporated. Steam heat can be calculated through the equation below:

$$
\mathrm{Q}=\mathrm{m}_{\mathrm{w}} \times \mathrm{U}
$$

Where, $\mathrm{Q}$ is quantity of energy or heat (Joule), $\mathrm{m}_{\mathrm{w}}$ is mass of the substance $(\mathrm{kg})$, and $U$ is steam heat (Joule $/ \mathrm{kg}$ ).

The drying process can be described through psychrometric charts [8]. The air condition during the drying process can be seen on the psychrometric charts. The drying process begins with an increase of the temperature from the air due to the heating air supplied in the drying chamber. The rising of the air temperature can be seen on the psychrometric chart by shifting the start point of the air to the right indicated by the increase of the air temperature of dry bulb. The next process is the mass transfer by evaporating the water content of the fish. The evaporation process is indicated by the rising point of the heating air condition on the psychrometric chart towards the top left. This is as the result of rising water content in the air after the process of water evaporation from the product into the air.

Forced convection consists of the heat transfer by the convection and conduction process. The heat carried by the flow of the fluid is able to enter into the material and the process of heat transfer from high to low temperatures can occur [9]. The energy carried by the flow of the fluid penetrates into the material and heated. It can be calculated through the equation below:

$$
\mathrm{Q}=\mathrm{HA}\left(\mathrm{T}_{\mathrm{s}}-\mathrm{T}\right)
$$

Where:

$\mathrm{Q}=$ Total convection energy (Joule)

$\mathrm{H}=$ Convection coefficient $\left(\mathrm{W} / \mathrm{m}^{2} \mathrm{~K}\right)$

$\mathrm{T}_{\mathrm{s}}=$ Surface temperature $(\mathrm{K})$

$\mathrm{T}=$ Material temperature $(\mathrm{K})$

\section{Simulation Design}

The design of the fish drying machine is modeled with three-dimensional geometry that has been simplified. The chamber size in this modeling is in the length $(\mathrm{x})$ of $80 \mathrm{~cm}$, width (y) of $60 \mathrm{~cm}$, and height (z) of $120 \mathrm{~cm}$. The dimension of the solar collector in this model is $80 \mathrm{~cm}$ long, $150 \mathrm{~cm}$ wide and $20 \mathrm{~cm}$ high. The results of the modeling can be seen in the figure below.

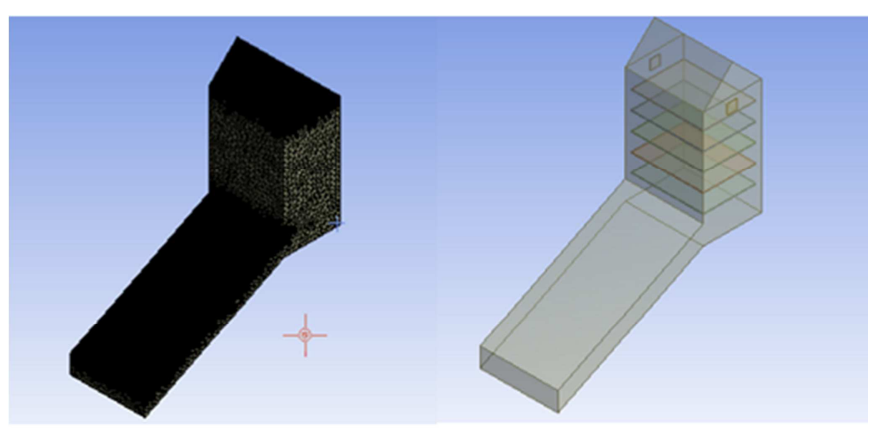

(a)

(b)

Figure 2. (a) The design; (b) The meshing.

The three-dimensional image has also meshed with the 
tetrahedral-hybrid type as shown in the Figure 2 (b). Mesh volume with $0.01 \mathrm{~m}$ interval produces 642371 elements. Furthermore, the boundary conditions and the types of the continuum are given in the table 1 as follows.

Table 1. Boundary conditions.

\begin{tabular}{ll}
\hline Part of Fish Drying Machine & Boundary Condition \\
\hline Chamber \& Solar Collector Wall & Wall \\
Collector Glass & Wall \\
Chamber Glass & Wall \\
Tray & Wall \\
Inlet & Velocity Inlet \\
Outlet & Pressure Outlet \\
\hline
\end{tabular}

After the boundary conditions are determined, the type of the continuum is selected for the volume of the fish drying machine and the solid type for the volume of the mattress. Then it simulated by mass and heat transfer processing due to the phenomena of convection and radiation in the machine. The values entered at the boundary conditions are taken from the data of temperature measurement and velocity of air flow at several represent points.

\section{Result and Discussion}

The completion stage uses a solver with 3DDP (3 Dimensions Double Precision) method. At this stage, the determination of material, calculation of physical-mathematical equations, operating conditions, boundary conditions, and settlement techniques are carried out. The simulation using steady condition consists of physical equations such as energy equations, the viscosity of the k-omega model, and the Surface to Surface (S2S) radiation model. S2S model is chosen because it is suitable for solar collectors to convey the heat by the convection. In this study, several models are conducted to determine the effect of the variations in mass and blower speed. The mass variations consist of $1 \mathrm{~kg}, 2 \mathrm{~kg}$, and $5 \mathrm{~kg}$ in a chamber. The blower variations are 1500 RPM, 1650 RPM, and 1800 RPM. The blower variations are based on the blower specification. There are 5 trays in one chamber. The temperature contours as the result of the simulation are shown in the figure 3 . The following data represent the temperature for 6 hours of drying time from 9 a.m. to 2 p.m.

Every tray has a varied temperature represented in the graph on Figure 4 with a speed of wind is $0.9 \mathrm{~m} / \mathrm{s}$. The highest average temperature value of the fish was obtained at 11 a.m. This is in accordance with the amount of solar irradiation received by the machine. The highest temperature is $36.88^{\circ} \mathrm{C}$ and the minimum temperature is $36.33^{\circ} \mathrm{C}$ at $2 \mathrm{p} . \mathrm{m}$. for $5 \mathrm{~kg}$ of fish. The heat transfer process begins with solar radiation that enters the fish drying machine, then continued with the conduction process through the iron plate resulting of the convection process in the machine. The drying process assisted by a fan to increase the heat moving rapidly. Losses have occured from the heat transfer process, it is necessary to calculate heat entering the fish through an evaporation process that is able to evaporate the water mass in the fish. From the figure 5 below, it can be seen that the drying rate increased as the decreasing of the mass.

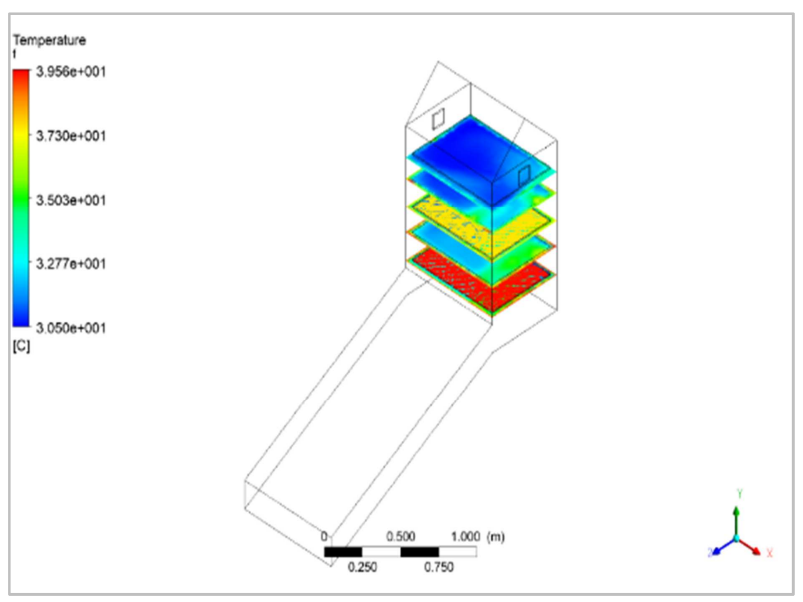

(a)

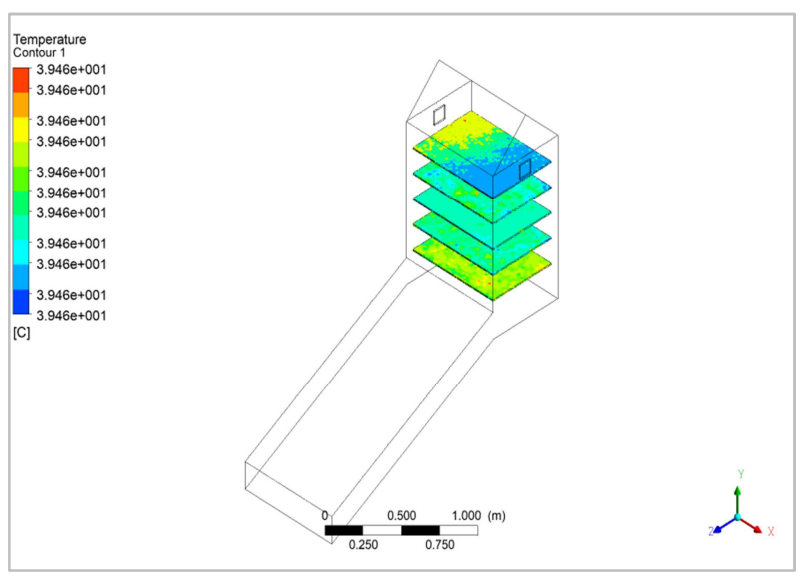

(b)

Figure 3. Contours of temperature (a) Environment; (b) Fish.

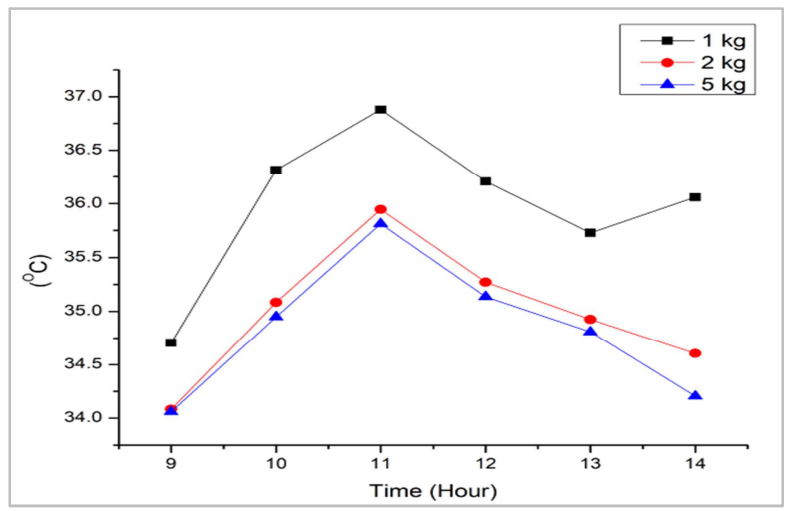

Figure 4. Fish temperature at $0.9 \mathrm{~m} / \mathrm{s}$ wind speed.

Optimization aims to make this machine work optimally. Therefore, it needs to increase the blower speed variations of 1650 RPM and 1800 RPM. From the figure 6, it can be seen that if the speed increases then the temperature will also increase. This is in accordance with the theory of kinetic gas that explains the relationship between speed and temperature is comparable, because the particles in a certain room move 
faster due to the speed increase. After finding out the temperature value at each speed, it was obtained the efficiency of $23.89 \%$ and $23.23 \%$ for the speed of 1650 RPM and 1850 RPM respectively.

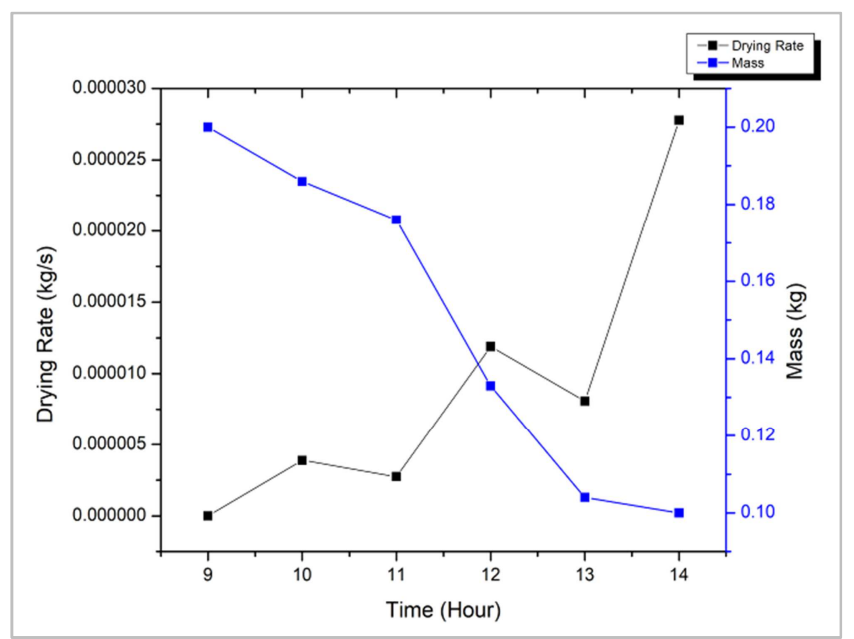

Figure 5. Drying rate.

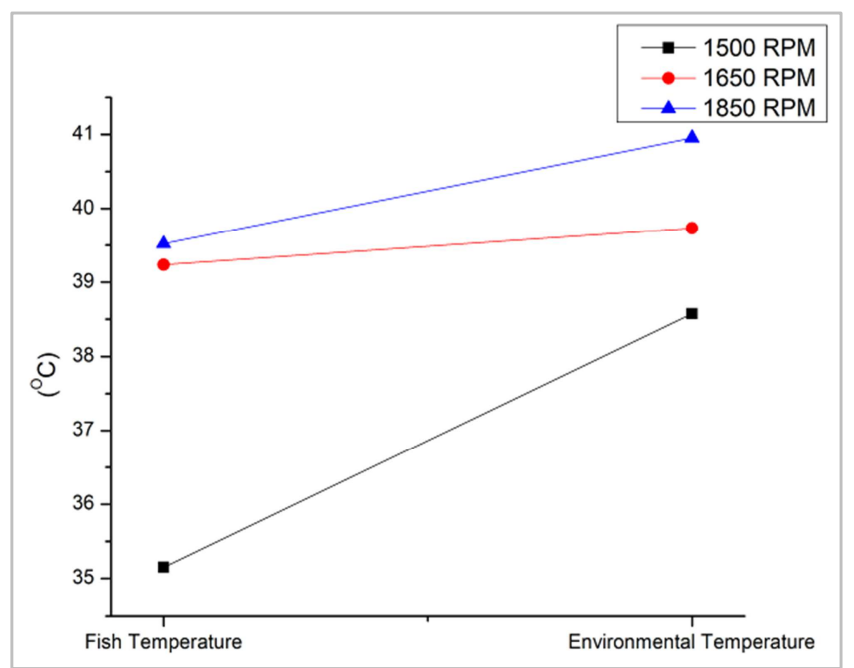

Figure 6. Blower speed variations.

\section{Conclusion}

From the experimental test we have done [4], the fish will be suitable for consumption if the moisture content of the fish is below $10 \%$ and the mass of fish water evaporated approximately $50 \%$ of the mass of wet fish. From the simulation, it is obtained the error values of the decrease in water vapor mass are $4.3 \%$ and $13.2 \%$ respectively for the mass variations of $2 \mathrm{~kg}$ and $5 \mathrm{~kg}$. Therefore, for the mass of 5 $\mathrm{kg}$ is overloaded because it has an error above $10 \%$. The fish drying machine has the blower speed of 1500 RPM and is able to release the heat of $82 \mathrm{~W}$ with an efficiency of $19 \%$. To optimize the machine, it needs to increase the blower speed up to $1650 \mathrm{RPM}$ and $1800 \mathrm{RPM}$ for the mass of $2 \mathrm{~kg}$, so this machine is able to release the heat of $89.11 \mathrm{~W}$ and $89.95 \mathrm{~W}$ and has the efficiency of $23 \%$.

\section{References}

[1] Handoyo, Ekadewi. 2012. Disain dan Pengujian Sistem Pengering Ikan Bertenaga Surya. Univesitas Kristen Petra. Surabaya.

[2] Abdjul, Sukarmanto. 2012. Rancang Bangun Alat Pengering Ikan Asin Efek Rumah Kaca Berbentuk Prisma Segi Empat Dengan Variasi Batu Sebagai Penyimpan Panas. Politeknik Gorontalo.

[3] Kumar, et al. 2015. Progress in solar Fish Drying Machines for drying various commodities. Renewable and Sutainable Energy Reviews 55 (2016) 343-360.

[4] Hantoro, et al. 2018. Solar Dryer and Photovoltaic for Fish Commodities (Case Study in Fishery Community at Kenjeran Surabaya). AIP Conference Proceeding 1977, 060013 (2018).

[5] Fudholi, et al. 2015. Review of solar drying systems with air based solar collectors in Malaysia. Renewable and Sutainable Energy Reviews 51 (2015) 1191-1204.

[6] Singh, Prashant, et al. 2015. Applications of Software in solar drying system: A review. Energy Centre, Maulana Azad Naaational Institute of Technology, India.

[7] Stocker, Wilbert F and Jones, Jerold W. 1982. Refrigerasi dan Pengkondisian Udara. Edisi Kedua. Diterjemahkan oleh Supratman Hara. Erlangga. Jakarta.

[8] Ferianto. 2013. Studi Eksperimen Pengaruh Variasi Temperatur dan Kecepatan Udara Pengering Terhadap Karakteristik Pengeringan Batubara Pada Coal Fish Drying Machine dengan Tube Heater tersusun Staggered. Teknik Mesin ITS. Surabaya.

[9] Al-Kayiem, Hussain. 2015. On the Natural Convection Heat Transfer in a Rectangular Passage Solar Air Heater. Mechanical Eng. Dept. Universiti Teknologi PETRONAS.

[10] Syaiful, M. 2009. Profil Suhu Pada Proses Pengeringan Produk Pertanian Dengan Simulasi Computational Fluid Dynamics (CFD). Jurusan Teknik Mesin. Fakultas Teknik Universitas Bengkulu.

[11] Blowerani, Indriyati. 2013. Studi Eksperimental Sistem Pengering Tenaga Surya Menggunakan Tipe Green House dengan Kotak Kaca. Teknik Fisika ITS. Surabaya.

[12] Kudariyawar, Jayaraj Y. 2015. Computational and Experimental Investigation of Steady State and Transient Characterisctics of Molten Salt Natural Circulation Loop. Homi Bhabha National Institute. Mumbai. India.

[13] Anderson, John D. 1995. Computational Fluid Dynamics The Basics With Applications. McGraw-Hill. 